\title{
BAX Gene
}

National Cancer Institute

\section{Source}

National Cancer Institute. BAX Gene. NCI Thesaurus. Code C18324.

This gene is involved in the regulation of apoptosis by binding p53 protein, which accelerates this mechanism of cell death. 